\title{
Transparency in International Arbitration: Any (Concrete) Need to Codify the Standard?
}

\author{
Gabriele Ruscalla*
}

DOI: $10.21827 / 5 a 86 a 86689122$

\section{Keywords}

INVESTOR-STATE ARbitRATION; REFORMS; TRANSPARENCY; LEgITIMACY; HOMESTATES' AMicus CURIAE SUBMISSIONS

\begin{abstract}
In the last decades, transparency has become a fundamental principle in international adjudication. It is usually defined as including concepts such as public access and disclosure of documents or information.

Due to the high impact of the activities of international institutions on civil societies and the growing relevance of individuals as subjects of the International Community, it became evident that there was a need to: 1. make the decision-making processes of international organisations more transparent; 2 . increase the accountability of the international institutions towards civil societies; 3 . give access to the public to international dispute settlement mechanisms.

For the purpose of this article, the third aspect, ie access to the public to international dispute settlement mechanisms, will considered. In particular, even though reference will be made to other international dispute settlement systems, the practice of international investment and commercial arbitral tribunals will be dealt with.

The article will then study the role of transparency in international arbitration, highlighting three main challenges. First, the author will consider the difficult relation between transparency and confidentiality in arbitral proceedings. As this issue is extremely delicate in international commercial arbitration, this practice will be the focus of this section of the article.

Second, transparency as a tool to reach a higher level of consistency in international arbitration will be discussed. This is a highly topical issue in international arbitration, as shown by the United Nations Commission on International Trade Law (UNCITRAL) negotiations that led to the adoption in 2014 of the Rules on Transparency in Treatybased Investor-State Arbitration. As a matter of fact, UNCITRAL looked into the issue of amicus curiae briefs provided by the investor's home State on issue of treaty interpretation, to secure more consistent and harmonised interpretations of standards in investment arbitration. The author will explore whether consistency through transparency is desirable in international arbitration.

Third, the paper will deal with the growing tendency to codify standards in international arbitration. This phenomenon is well illustrated by the current negotiations on investment and trade treaties such as the EU-US Transatlantic Trade and Investment Partnership (TTIP) and the EU-Canada Comprehensive Economic and Trade Agreement
\end{abstract}

Senior Research Fellow, Department of Dispute Resolution and International Law, Max Planck Institute Luxembourg for International, European and Regulatory Procedural Law. The views expressed in this article are those of the author and do not necessarily represent the views of, and should not be attributed to, the Max Planck Institute Luxembourg. 
(CETA) that provide for specific provisions on transparency relating to investor-to-State disputes. The necessity and effectiveness of this codification will be investigated.

\section{Introduction}

The concept of transparency in international law is broad and has three distinct dimensions. 'Institutional transparency' is the level of transparency that international organisations and institutions apply to their daily activities. ' 'Legislative transparency' evaluates the level of transparency of the law-making processes in international law. ${ }^{2}$ 'Procedural transparency' concerns the way international courts and tribunals apply and enforce international legal norms. ${ }^{3}$

However, achieving a single definition of transparency in international law is difficult because the international legal arena is a 'universe of inter-connected islands', where fragmentation seems to prevail over unity. ${ }^{4}$ Each area of international law has developed its own substantive and procedural rules and the international community has established as many international courts and tribunals as there are areas of international law. As a result, it seems that a single concept of transparency for all fields of international law cannot arise. ${ }^{5}$

International investment law and arbitration have been criticised by important actors in the field - mostly academics and non-governmental organisations (NGOs) - that regularly claim a lack of transparency. These criticisms are mainly directed at the investor-State dispute settlement (ISDS) mechanisms provided for by International Investment Agreements (IIAs), due inter alia to the existing tension between confidentiality and transparency in international arbitration. While legal commentators note inconsistent interpretations of international investment law standards, ${ }^{6}$ political and

1 Major international organisations have undertaken programs promoting accountability through transparency. See for instance, the several initiatives, such as the United Nations, Strengthening Accountability, at <un.org/en/strengtheningtheun/accountability.shtml> (accessed 10 May 2015) and the European Commission, Transparency Portal, at <ec.europa.eu/transparency/index_en.htm> (accessed 5 May 2015).

2 The online public consultation on investment protection and investor-State dispute settlement (ISDS) in the Transatlantic Trade and Investment Partnership (TTIP) agreement was launched by the European Commission on 27 March 2014. Such initiative clearly shows that international institutions have started acknowledging the relevance of the inclusion of all stakeholders interested in the negotiation of multilateral treaties. See the dedicated website of the European Commission, Trade: Consultations: Online public consultation on investment protection and investor-to-state dispute settlement (ISDS) in the Transatlantic Trade and Investment Partnership Agreement (TTIP), concluded 13 July 2014, at $<$ trade.ec.europa.eu/consultations/index.cfm?consul_id=179> (accessed 20 May 2015)

3 Delaney, J and Barstow Magraw Jr, D, "Procedural Transparency", in Muchlinski, P, Ortino, F and Schreuer, C, eds, The Oxford Handbook of International Investment Law, (Oxford University Press, 2008), 721.

4 Pauwelyn, J, "Bridging Fragmentation and Unity: International Law as a Universe of Inter-Connected Islands", 25 Michigan Journal of International Law (2004) 903.

5 See for instance, Bianchi, A and Peters, A, eds, Transparency in International Law (Cambridge University Press, Cambridge, 2013). The authors analysed the concept of transparency as applied to the several fields of international law (ie, international environmental law, international economic law, international human rights law, international health law, international humanitarian law, international peace and security law), showing that a general definition of 'transparency in international law' does not exist.

6 Banifatemi, Y, "Consistency in the Interpretation of Substantive Investment Rules", in Echandi, R and Sauvé, P, eds, Prospects in International Investment Law and Policy (Cambridge University Press, 2013), 200. 
social observers condemn the legitimacy crisis of the arbitration system as a whole. ${ }^{7}$ This perception is particularly strong in investment arbitration where public interests are directly involved. ${ }^{8}$

In international law, transparency encompasses several procedural values, notably access to parties' written and oral submissions, public accessibility to hearings and communication (ie publication) of the judicial decision. ${ }^{9}$ If we limit the scope of transparency to international investment law and arbitration, it 'generally takes the form of disclosure to third parties or of third-party participation in arbitral proceedings. ${ }^{10}$ The United Nations Commission on International Trade Law (UNCITRAL) Working Group II on Arbitration and Conciliation has agreed that

[T] he substantive issues to be considered in respect of the possible content of a legal standard on transparency would be as follows: publicity regarding the initiation of arbitral proceedings; documents to be published (such as pleadings, procedural orders, supporting evidence); submission by third parties ("amicus curiae") in proceedings; public hearings; publication of arbitral awards; possible exceptions to the transparency rules; and repository of published information ("registry"). ${ }^{11}$

In particular, the access of non-disputing actors to parties' submissions is relevant in arbitration proceedings for at least two reasons. First, legal experts as well as the general public can get information concerning the development of a specific procedure. As we mentioned above, information is particularly important and ever more demanded in international investment arbitration, where public interests are at stake. Second, access to documents gives non-disputing parties the opportunity to intervene in proceedings through an amicus curiae submission. ${ }^{12}$ These submissions have two main general purposes: either they discuss in a critical way a matter falling within the dispute, or they interpret a treaty provision. ${ }^{13}$

7 United Nations Conference on Trade and Development (UNCTAD), Transformation of the international investment agreement regime, 17 December 2014, TD/B/CII/EM4/2, 3.

$8 \quad I d, 4$ :

(a) Legitimacy. It is questionable whether three individuals, appointed on an ad hoc basis, can be entrusted with assessing the validity of States' acts, particularly when they involve public policy issues. The pressures on public finances and potential disincentives for public-interest regulation may pose obstacles to countries' sustainable development paths;

(b) Transparency. Although the transparency of the system has improved since the early 2000s, ISDS proceedings can still be kept fully confidential if both disputing parties so wish, even in cases where the dispute involves matters of public interest.

9 Nuemann, T and Simma, B, "Transparency in International Adjudication", in Bianchi, A and Peters, A, eds, Transparency in International Law (Cambridge University Press, Cambridge, 2013) 436, 437.

10 Feliciano, FP, "The "Ordre Public" Dimensions of Confidentiality and Transparency in International Arbitration: Examining Confidentiality in the Light of Governance Requirements in International Investment and Trade Arbitration", in Nakagawa, J, ed, Transparency in International Trade and Investment Dispute Settlement (Routledge, Oxon, 2013), 19.

11 United Nations Commission on International Trade Law (UNCITRAL), REPORT: Settlement of commercial disputes: preparation of a legal standard on transparency in treaty-based investor-State arbitration, Working Group II (Arbitration and Conciliation) of the work of its fifty-third session (Vienna, 4-8 October 2010), A/CN9/712, 20 October 2010, para 31.

12 Nuemann and Simma, supra nt 9, 437-348.

13 In international investment arbitration, the first type of amicus curiae is often submitted by nongovernmental organisations whereas the second type is usually presented by the investor's home State. 
As discussed further below, this latter type of amicus curiae is seen as a potential instrument to increase harmonisation and consistency of investment treaty interpretation. It is then in this regard that the connection between transparency, consistency and legitimacy in international investment law is established. The legal theorist, Thomas Franck, has stated that 'requirements about how rules are made, interpreted and applied' are necessary to define a system of rules as fair and legitimate ${ }^{14}$

Four elements - the indicators of rule legitimacy in the community of states-are identified ... determinacy, symbolic validation, coherence and adherence (to a normative hierarchy). To the extent rules exhibit these properties, they appear to exert a strong pull on states to comply with their commands. To the extent these elements are not present, rules seem to be easier to avoid by a state tempted to pursue its short-term self-interest. ${ }^{15}$

The term coherence should be understood as the 'consistency of the rule and its application with other rules'. ${ }^{16}$ UNCITRAL took a similar position during negotiations for the Rules on Transparency in Treaty-based Investor-State arbitration ${ }^{17}$

[Transparency] was also seen as an important step to respond to the increasing challenges regarding the legitimacy of international investment law and arbitration as such. Those challenges were said to include, among others: an increasing number of treaty-based investor-State arbitrations, including an increasing number of frivolous claims; increasing amounts of awarded damages; increasing inconsistency of awards and concerns about lack of predictability and legal stability; and uncertainties regarding how the investor-State dispute settlement system interacted with important public policy considerations. It was said that legal standards on increased transparency would enhance the public understanding of the process and its overall credibility. ${ }^{18}$

Having briefly described the link between transparency, consistency and legitimacy in international investment law and arbitration (Figure 1 below), the article will first analyse the tension between transparency and confidentiality in international arbitration (section II). In this section, both values will be dealt with in general terms, encompassing all stages of arbitration proceedings (ie access to documents, public hearings, submission of third parties and publication of the awards).

Then, the relation between transparency through the publication of awards, the establishment of (or the refusal to establish) a doctrine of precedents in investment

14 Franck, TM, Fairness in International Law and Institutions (Clarendon Press, Oxford, 1995), 7-8.

15 Franck, TM, "Legitimacy in the International System", 82 American Journal of International Law (1988) 705,712 .

16 Brunnee, J and Toope, SJ, Legitimacy and Legality in International Law: An Interactional Account (Cambridge University Press, Cambridge, 2010), 53.

17 UNCITRAL, UNCITRAL Rules on Transparency in Treaty-based Investor-State Arbitration, effective 1 April 2014 (UNCITRAL Rules on Transparency) or (Rules on Transparency).

18 UNCITRAL, REPORT: Settlement of commercial disputes: preparation of a legal standard on transparency in treaty-based investor-State arbitration, Working Group II (Arbitration and Conciliation) of the work of its fifty-third session (Vienna, 4-8 October 2010), A/CN9/712, 20 October 2010, para 17 [emphasis added]. 
arbitration and the possibility to increase consistency of the law will be considered and analysed (section III).

Next, the issue of non-disputing parties' submissions will be discussed. This is a highly topical issue as the UNCITRAL work on the 2014 Rules on Transparency shows. As a matter of fact, UNCITRAL looked into the issue of amicus curiae briefs both to secure more consistent and harmonised interpretations of investment law standards and to increase legitimacy of the system (section IV).

Finally, the article will deal with the growing trend to codify transparency standards that were not included in previous IIAs. This phenomenon is well-illustrated by the investment policies of Canada and the United States (section V).

Figure 1. The Connection Between Transparency, Consistency and Legitimacy in International Investment Law and Arbitration

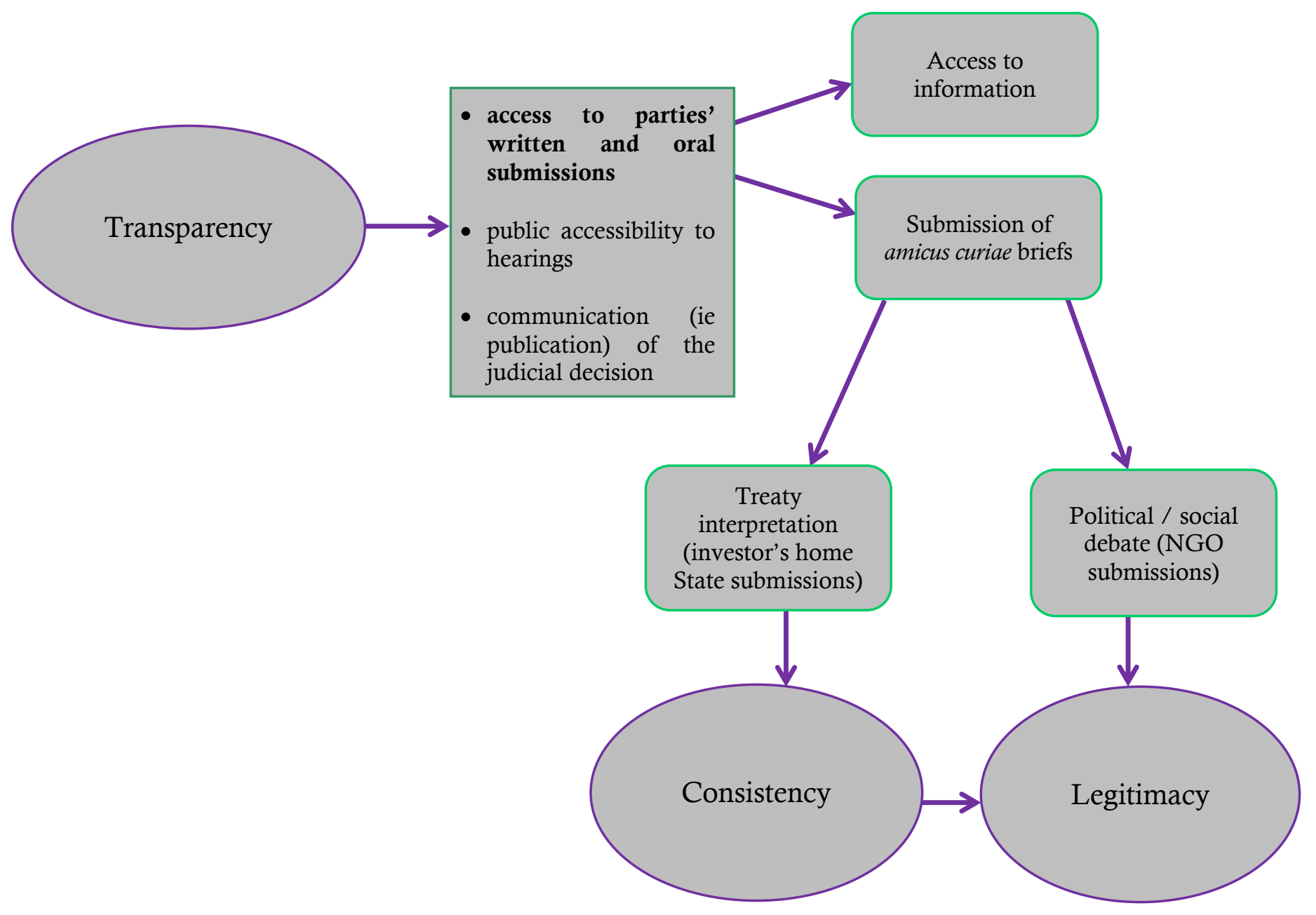




\section{Transparency and Confidentiality: Are They Competing Values?}

Confidentiality and transparency are both general values of international arbitration. They have been described as 'competing values', but some scholars have seen the possibility of adjusting one to the other depending on the specific case. ${ }^{19}$ Is confidentiality the big enemy of transparency? If one considers State-to-State adjudication, the answer seems to in the affirmative. In the words of an international law scholar

Transparency epitomizes the prevailing mores in our society and becomes a standard of (political, moral and, occasionally, legal) judgment of people's conduct. ... In contrast, the opposites of transparency, such as secrecy and confidentiality, have taken on a negative connotation. Although they remain paradigmatic narratives in some areas, overall they are largely considered as manifestations of power, and, often, of its abuse. ${ }^{20}$

As regards international arbitration, the discussion is more complicated because both private and public interests are directly involved in the dispute. Confidentiality is thought of as an instrument to protect the interests of both the foreign investor and the host State. In international economic relations, reputation is essential: the actors involved in arbitration proceedings might not want to expose their business conduct to the international community. ${ }^{21}$ This is why documents relating to the procedure and awards are often categorised as undisclosable confidential information. Also, confidentiality might protect the ad hoc essence of international arbitration that resolves 'individualised disputes between individual parties and only those parties'. ${ }^{22}$

\section{II.1. 'Conservative' Views Promoting Confidentiality}

It is well known in international commercial arbitration ${ }^{23}$ that, even if it is not the primary reason, ${ }^{24}$ transnational corporations prefer international arbitration because their business secrets and confidential information are better protected than in international litigation. Some international arbitration experts favor maintaining this standard because they consider it as 'one of the attractions of arbitration in the eyes of arbitration users'. ${ }^{25}$

19 Buys, CG, "The Tensions between Confidentiality and Transparency in International Arbitration", 14 The American Review of International Arbitration 121, 121. See also, Feliciano, supra nt 9, 20.

20 Bianchi, A, "On Power and Illusion: The Concept of Transparency in International Law", in Bianchi, A and Peters, A, eds, Transparency in International Law (Cambridge University Press, Cambridge, 2013), 2 .

21 Ortino, F, "Transparency of Investment Awards: External and Internal Dimensions", in Nakagawa, J, ed, Transparency in International Trade and Investment Dispute Settlement (Routledge, Oxon, 2013), 132.

22 Banifatemi, Y, "Mapping the Future of Investment Treaty Arbitration", American Society of International Law - Proceedings of the 103rd Annual ASIL Meeting (2010) 323, 325.

23 For an analysis of the confidentiality in international commercial arbitration, see, Smeureanu, IM, Confidentiality in International Commercial Arbitration (Kluwer Law International, Alphen aan den Rijn, 2011). See also, Müller, C, "La confidentialité en arbitrage commercial international: un trompe-l'œil?", 23(2) ASA Bulletin 216 (2005).

24 Buys, supra nt 19, 122.

25 Gaillard, E, and Savage, J, Fouchard, Gaillard, Goldman on International Commercial Arbitration (Kluwer Law International, Alphen aan den Rijn, 1996), 733. See also Lazareff, S, "Confidentiality and 
Supporters of this view also stress that not only the arbitral procedure should be confidential but also the outcome of that procedure, thus preventing the publication of the arbitral award. ${ }^{26}$ The same idea was expressed by a former secretary general of the Court of International Arbitration of the International Chamber of Commerce (ICC), who acknowledged that 'indeed it became quickly apparent to me that should the ICC adopt a publication policy or any other policy, which would mitigate or diminish the strict insistence on confidentiality by the ICC, this would constitute a significant deterrent to the use of ICC arbitration'. ${ }^{27}$

In international investment arbitration, confidentiality is considered an even more delicate issue. If it is true that public interests are regularly at stake in investor-State international economic relations, most IIAs were negotiated and concluded in an era when procedural transparency was not considered a topical issue in international arbitration. Also, most IIAs 'refer to mechanisms inspired by international commercial arbitration as the main option for investor-State dispute settlement which is by nature based on confidentiality of the proceedings' ${ }^{28}$ This is not surprising as, despite international law being always applicable as substantive law in investment arbitration, the procedure in investment arbitration is not 'different from the arbitral process generally [because] [i]nvestment treaty arbitration can be properly defined as a "sub-system" of international arbitration'. ${ }^{29}$ Moreover, it is generally recognised that International Centre for Settlement of Investment Disputes (ICSID) arbitration has adopted the structure, forms and procedures of commercial arbitration. The fact that IIAs include commercial arbitration as dispute resolution options in their ISDS shows how commercial arbitration has influenced the shape of the ICSID regime. ${ }^{30}$

Among the arbitral institutions, the London Court of International Arbitration (LCIA) has adopted the more conservative arbitration rules (LCIA Rules) in relation to confidentiality, ${ }^{31}$ with the presumption that the entire arbitration proceeding is confidential. Article 30 states that all awards, materials, and documents, ${ }^{32}$ as well as the

Arbitration: Theoretical and Philosophical Reflections", ICC Bulletin-Special Supplement (2009) 81, 8182:

What an absurdity to postulate that confidentiality is not part and parcel of commercial arbitration. It is inconceivable that such a procedure, whether domestic or international, should take place in the public eye ... Confidentiality thus has its roots in the desire for a system of justice suited to the world of commerce ... Confidentiality is justified in particular by the need to maintain the secrecy inherent in business dealings;

Trackman, LE, "Confidentiality in International Commercial Arbitration", 18(1) Arbitration International (2002) 1.

26 Loquin, E, "Les Obligations de Confidentialité dans l'Arbitrage", 2 Revue de l'Arbitrage (2006) 323, 344.

27 Bond, S, "Expert Report of Stephen Bond Esq (in Esso/BHP v Plowmann)", 11(3) Arbitration International (1995) 273, para 6. See also, Born, GB, International Commercial Arbitration, (2nd ed, vol II, Kluwer Law International, Alphen aan den Rijn, 2014), 2782: "Confidentiality of the arbitral proceedings serves to centralize the parties' dispute in a single forum and to facilitate an objective, efficient and commerciallysensitive resolution of the dispute, while also limiting disclosure to of the parties' confidences to the press, public, competitors and others".

28 UNCITRAL, Note by the Secretariat - Settlement of commercial disputes: Preparation of rules of uniform law on transparency in treaty-based investor-State dispute settlement, A/CN9/WGII/WP160, 5 August 2010, 5.

29 Banifatemi, Mapping the Future of Investment Treaty Arbitration, supra nt 22, 324.

30 McLachlan, QC, "Investment Treaty Arbitration: The Legal Framework", in van den Berg, AJ, 50 Years of the New York Convention, (ICCA Congress Series No 14, Kluwer Law International, Alphen aan den Rijn, 2009) 95, 98-100.

31 London Court of International Arbitration (LCIA), LCIA Arbitration Rules, effective 1 October 2014 (LCIA Rules).

32 Article 30(1), LCIA Rules. 
deliberations $^{33}$ of the arbitral tribunal are confidential. Moreover, the award is not published $^{34}$ and hearings are held in private, ${ }^{35}$ unless all parties agree in writing. If the parties agree on the publication of the award, the rules require that the arbitral tribunal has to be favourable to this as well. ${ }^{36}$

Similar provisions are contained in the Swiss Rules of International Arbitration (Swiss Rules) ${ }^{37}$ that provide for privately held hearings ${ }^{38}$ as well as full confidentiality of awards, orders, and materials, ${ }^{39}$ unless the parties otherwise agree in writing. Unlike the LCIA Rules, deliberations of the arbitral tribunal are always confidential and no exception is laid down. ${ }^{40}$ As for the publication of the award, the procedure requires both parties to agree to $\mathrm{it}^{41}$ and the final decision lies with the Secretariat of the Swiss Chambers' Arbitration Institution. ${ }^{42}$

\section{II.2. 'Progressive' Views: Less Confidentiality, More Transparency}

With investor-State arbitration cases increasing, civil society and other actors in the international investment regime have started demanding more openness and transparency in arbitral proceedings. ${ }^{43}$ In particular, the general public has expressed interest in participating in the system, in observing the activities of foreign investors and in evaluating the host State's exercise of public functions in their economic relations with foreign investors. ${ }^{44}$ However, transparency is not only an issue in investment arbitration. International commercial arbitration can be affected by the tension between transparency and confidentiality for at least five reasons.

First, even though commercial arbitrations are usually conducted between private parties, one of the disputing parties can be a State, a State entity or a State instrumentality. In fact, a State can act both in its sovereign capacity (jure imperii) under public international law and participate in international commercial arbitrations in its private capacity (jure gestionis). ${ }^{45}$ In the latter case, the public interest can be involved in purely commercial international arbitrations. Second, due to this presence of public interest issues, the general public could be affected by the outcome of a commercial arbitration proceeding in several ways. ${ }^{46}$ Examples of public interests at stake in commercial arbitration include inter alia cases dealing with national defence issues,

33 Article 30(2), LCIA Rules.

Article 19(4), LCIA Rules.

Article 30(3), LCIA Rules.

Article 30(3), LCIA Rules.

37 Swiss Chambers' Arbitration Institution, Swiss Rules of International Arbitration, effective 1 June 2012 (Swiss Rules).

38 Article 25(6), Swiss Rules.

39 Article 44(1), Swiss Rules.

40 Article 44(2), Swiss Rules.

41 Article 44(3)(c), Swiss Rules.

42 Article 44(3)(a), Swiss Rules.

43 Schreuer, C, Malintoppi, L, Reinisch, A and Sinclair, A, The ICSID Convention: A Commentary (2nd ed, Cambridge University Press, Cambridge, 2009), 697-698.

44 Ortino, supra nt 21, 133-134.

45 Heiskanen, V, "State as a Private: The Participation of States in International Commercial Arbitration", 7 Transnational Dispute Management (2010) 1, 2.

46 Buys, supra nt 19, 135. 
agriculture, a State's oil, gas and other natural resources, commercial embargoes and telecommunications. ${ }^{47}$

Third, transparency is fundamental in those commercial arbitration cases where misconduct or unlawful activities (for example, corruption, bribery, money laundering and fraud) have been committed by public officers or by officials of foreign transnational corporations. ${ }^{48}$ In such cases, (transnational) public policy prevails over confidentiality. Fourth, confidentiality can also affect the development of the so-called autonomous arbitral legal order. ${ }^{49}$ In particular, if compared with a national judge who is considered a real actor in the domestic legal order, '[L]a parole de ce prophète [the arbitrator] demeure confidentielle; il ne peut pas être, comme le juge, un véritable acteur de l'ordre juridique. La voix de l'arbitre n'est pas audible, ou difficilement dans la société'. ${ }^{50}$ Fifth, confidentiality can also be dangerous for the arbitral procedure. In fact, when confidential, an award

may be just part of a series of other (related or unrelated) awards which may reinforce or contradict the submitted award's conclusion. Neither the tribunal nor the other party may be aware of the fact that the award submitted is just one part of a larger puzzle selected by the submitting party with its tactical preferences in mind. ${ }^{51}$

As a consequence, one of the parties or even the arbitral tribunal could miss the broader picture of a case.

In accordance with this tendency to downplay confidentiality in international arbitration, some scholars argue that the principle of confidentiality in international

47 See for instance, Romero, ES, "Are States Liable for the Conduct of Their Instrumentalities? ICC Case Law" in Gaillard, E and Younan, J, eds, State Entities in International Arbitration (IAI Series on International Arbitration No 4, Juris Publishing, 2008), 31. See also ICC Commission on Arbitration and ADR, REPORT: States, State Entities and ICC Arbitration, ICC Document 862-1 ENG, 2012, at $<$ iccwbo.org/Advocacy-Codes-and-Rules/Document-centre/2012/ICC-Arbitration-CommissionReport-on-Arbitration-Involving-States-and-State-Entities-under-the-ICC-Rules-of-Arbitration/> (accessed 5 May 2015), 3-4: The report gives States and State entities recommendations concerning their involvement in (private contractual) commercial arbitrations and investment arbitrations. 'As arbitration agreements for commercial arbitration involving states and state entities are formed differently from those in investment arbitration, the recommendations regarding each will be set out separately'.

48 Feliciano, supra nt 9, 20.

49 For a definition of the notion of 'autonomous arbitral legal order', see Fouchard, P, "L'Autonomie de l'Arbitrage Commercial International", 1965(1) Revue de l'Arbitrage (1965) 99; Oppetit, B, "Philosophie de l'Arbitrage Commercial International", 120(4) Journal du Droit International (1993) 811; Gaillard, E, "Souveraineté et Autonomie: Réflexions sur les Représentations de 1'Arbitrage International", 134(4) Journal du Droit International (2007) 1163; Gaillard, E, "L’Ordre Juridique Arbitral: Réalité, Utilité, Spécificité", 55 McGill Law Journal - Revue de Droit de McGill (2010) 891; Gaillard, E, Legal Theory of International Arbitration (Martinus Nijhoff, Leiden, 2010); Gaillard, E, "International Arbitration as a Transnational System of Justice", in van den Berg, AJ, ed, Arbitration: The Next 50 Years, (ICCA Congress Series 16, Kluwer Law International, Alphen aan den Rijn, 2012) 66; Gaillard, E, "Transcending National Legal Orders for International Arbitration", in, van den Berg, AJ, ed, International Arbitration: The Coming of a New Age? (ICCA Congress Series No 17, Kluwer Law International, Alphen aan den Rijn, 2013) 371.

50 (The dictum of this prophet [the arbitrator] is confidential; the arbitrator's voice is not audible beyond rare exceptions): Ancel, J-P, “L'Arbitre Juge”, 2012(4) Revue de l'Arbitrage (2012) 717, 723.

51 Wälde, T, "Confidential Awards as Precedent in Arbitration: Dynamics and Implication of Award Publication" in Banifatemi, Y, ed, Precedent in International Arbitration (IAI Series on International Arbitration No 5, Juris Publishing, 2008), 118. 
arbitration is not to be considered as lege $\operatorname{lata}^{52}$ and, even when the principle exists, its application depends on the specific circumstances of the case. ${ }^{53}$ National courts have followed the same approach. ${ }^{54}$ Only a few countries recognise the existence of an obligation of confidentiality in international arbitration. On the contrary, most jurisdictions provide for confidentiality only when it is established by the applicable law, by the lex arbitri or by consent of both parties. ${ }^{55}$ For instance, the English Arbitration Act of 1996 does not address the issue of confidentiality. As a result, despite the English common law considering confidentiality to be an implied term of every arbitration agreement, ${ }^{56}$ experts have advised the parties to expressly stipulate confidentiality in an arbitration agreement. ${ }^{57}$

In France, confidentiality in international arbitration is no longer the general rule under French law. The New French Arbitration Law ${ }^{58}$ distinguishes domestic arbitration from international arbitration. Confidentiality of arbitral proceedings is applied only to the former. ${ }^{59}$ The only requirement for confidentiality in international arbitration concerns an arbitral tribunal's deliberations. ${ }^{60}$ As in English law, French arbitration lawyers have recommended that the parties include, if they so wish, reference to confidentiality in any arbitration agreement. ${ }^{61}$

As a result, one can clearly state that confidentiality is not an overriding principle of international commercial arbitration as most arbitration statutes and arbitration rules do not contemplate a general principle of confidentiality. ${ }^{62}$ This is also implicitly recognised

52 Paulsson, J and Rawding, N, "The Trouble with Confidentiality", 5(1) ICC Bulletin (1994) 48. See also Delvolvé, J-L, "Vraies et Fausses Confidences, ou les Petits et les Grands Secrets de l'Arbitrage", (3) Revue de l'Arbitrage (1996) 373.

53 Poudret, J-F and Besson, S, Comparative Law of International Arbitration (Sweet \& Maxwell, London, 2007), 316.

54 Supreme Court of Sweden, Bulgarian Foreign Trade Bank Ltd v AI Trade Finance Inc (English translation), Case No T 1881-99, 27 October 2000; High Court of Australia, Esso Australia Resources Ltd and Consorts $v$ Plowman (1995) 183 CLR 10; United States District Court, United States v Panhandle Eastern Corporation, 119 FRD 346 (Del, 1988). See also Cour d'Appel de Paris (France), Société National Company for Fishing and Marketing "Nafimco" v Société Foster Wheeler Trading Company AG, 22 January 2004: The Cour d'Appel decided that 'la partie, qui requiert une indemnisation pour violation de la confidentialité de l'arbitrage doit s'expliquer sur l'existence et les raisons d'un principe de confidentialité dans le droit français de l'arbitrage international' (A party claiming for compensation for violation of confidentiality in an arbitration proceeding must prove the existence of a confidentiality principle in the French law on international arbitration). Such a request means that the existence of an obligation of confidentiality is not evident.

55 Feliciano, supra nt 9, 16.

56 Court of Appeal of England and Wales, Ali Shipping Corporation v Shipyard Trogir [1997] EWCA Civ 3054: In this case, the Court stated that all documents prepared for and used during the arbitration proceedings, transcripts, notes as well as the award are subject to confidentiality, unless the parties have otherwise agreed.

57 Gerbay, R, "Confidentiality vs Transparency in International Arbitration: The English Perspective", 9(3) Transnational Dispute Management (2012) 1, 3.

58 Code de procédure civile (Code of Civil Procedure), France (2005), as amended by Décret no 2011-48 du 13 janvier 2011 portant réforme de l'arbitrage (Decree No 2011-48 of 13 January 2011 reforming the law on arbitration), (New French Arbitration Law).

59 Article 1464(4), New French Arbitration Law.

60 Article 1506, New French Arbitration Law: referring to Article 1479.

61 Gaillard, E and de Lapasse, P, "Le Nouveau Droit Français de 1'Arbitrage Interne et International", 3 Recueil Dalloz (2011) 175, 184.

62 Kluwer Arbitration Blog, Mourre, A and Vagenheim, A, Arbitral Jurisprudence in International Commercial Arbitration: The Case for a Systematic Publication of Arbitral Awards in 10 Questions, 28 May 2009, at $<$ kluwerarbitrationblog.com/blog/2009/05/28/arbitral-jurisprudence-in-international-commercial- 
by those who strongly support the existence of such a general principle. For instance, Serge Lazareff - a supporter of confidentiality in international arbitration - admits that if the parties wish to benefit from maximum confidentiality, they should resort to a clause'. ${ }^{63}$ It is clear that, if parties need to explicitly agree to a clause, the principle contained in that clause cannot be considered generally recognised by the international arbitration community.

The tendency toward higher transparency in international arbitration is adopted by several institutional arbitration rules as well. 'Progressive' arbitration rules include those established by the American Arbitration Association (AAA Rules), ${ }^{64}$ the International Chamber of Commerce (ICC Rules), ${ }^{65}$ the Chamber of Arbitration of Milan (CAM Rules) ${ }^{66}$ and the Society of Maritime Arbitrators (SMA Rules) ${ }^{67}$

In the arbitration rules of the American Arbitration Association, confidentiality is still the general rule concerning all aspects of the proceedings, ${ }^{68}$ hearings are held privately, ${ }^{69}$ and awards are not published ${ }^{70}$ unless the parties have otherwise agreed. However, the provision concerning the publication of arbitral awards allows the institution to publish 'selected awards, orders, decisions, and rulings that have been edited to conceal the names of the parties and the identifying details', unless the parties have decided otherwise. $^{71}$

With regard to the ICC Rules, although proceedings are not generally open to third parties, access is given if the parties and the arbitral tribunal have so agreed. ${ }^{72}$ An important innovative provision in the ICC Rules is that the confidentiality rule is reversed compared to the LCIA and Swiss Rules. Article 22(3) states that

Upon the request of any party, the arbitral tribunal may make orders concerning the confidentiality of the arbitration proceedings or of any other matters in connection with the arbitration and may take measures for protecting trade secrets and confidential information. ${ }^{73}$

This means that confidentiality is not the general presumption in the ICC Rules. If a party does not raise a request for confidentiality, the arbitral tribunal is free not to apply this principle.

The CAM Rules do not include any provision on the participation of third parties at hearings. However, any third party participation is difficult to envisage as the confidentiality of arbitral proceedings and arbitration awards is fully protected. ${ }^{74}$ The original and more liberal provision is Article 8(2), which allows the institution, for the

arbitration-the-case-for-a-systematic-publication-of-arbitral-awards-in-10-questions.../> (accessed 6 May 2015).

63 Lazareff, supra nt 25, 88.

64 American Arbitration Association, International Dispute Resolution Procedures (Including Mediation and Arbitration Rules), effective 1 June 2014 (AAA Rules).

65 International Chamber of Commerce (ICC), ICC Rules of Arbitration, effective 1 January 2012 (ICC Rules).

66 Chamber of Arbitration of Milan, Arbitration Rules, effective 1 January 2010 (CAM Rules).

67 Society of Maritime Arbitrators, Maritime Arbitration Rules, effective 23 October 2013 (SMA Rules).

68 Article 23(6), AAA Rules.

69 Article 37(2), AAA Rules.

70 Article 30(3), AAA Rules.

71 Article 30(3), AAA Rules.

72 Article 26(3), ICC Rules.

Article 22(3), ICC Rules.

74 Article 8(1), CAM Rules. 
purposes of research, to publish the award in an anonymous format. The objection of a party may be raised exclusively during the proceedings - that is, before the award is rendered. ${ }^{75}$

The SMA Rules on arbitration proceedings show the most liberal approach: no provision on confidentiality is included in the text. As for third party access to the hearings, Section 17 establishes that 'persons having a direct interest in the arbitration are entitled to attend hearings' ${ }^{76}$ Finally, the institution publishes awards unless both parties object to publication before the award is issued. ${ }^{77}$ This approach is even more transparency-oriented than that of the CAM Rules. Whereas the CAM Rules require only one objection to the publication of the award, the SMA Rules state that both parties need to object in order to impede the publication of the final decision.

\section{Consistency Through Publication of Arbitral Awards: The Rise of a Stare Decisis Doctrine?}

Confidentiality, transparency and the establishment of a system of binding precedent are strictly connected. In fact, where decisions are not publicly available, precedents cannot develop. ${ }^{78}$ Legal precedents are used by judges in most national legal systems to ensure a more predictable, certain and foreseeable legal order. ${ }^{79}$ The use of precedent in domestic judges' reasoning facilitates this foreseeability. In international arbitration, as in international law, there is no directly or indirectly expressed obligation to follow legal precedent.

However, it is commonly recognised that, even though international jurisdictions are not bound to follow their own or other's precedents, ${ }^{80}$ a de facto case law has developed.$^{81}$ This is also true for jurisdictions dealing with international economic law issues such as the WTO dispute settlement system ${ }^{82}$ and international investment tribunals. ${ }^{83}$

75 Article 8(2), CAM Rules.

76 Section 17, SMA Rules.

77 See Society of Maritimes Arbitrators Inc, Publications, at <smany.org/sma-pubs.html> (accessed 5 May 2015).

78 Reinisch, A, "The Role of Precedent in ICSID Arbitration" in Zeiler, G, Welser, I, Power, J, Pitkowitz, N, Kremslehner, F, Klein, P and Klausegger, C, eds, 2008 Austrian Arbitration Yearbook (Manz'sche Verlags, Vienna, 2008), 495: 'That is exactly why precedent has played a relatively minor role in traditional international commercial arbitration which often remains confidential until resolution of a dispute'.

79 Guillaume, G, "The Use of Precedents by International Judges and Arbitrators", 2(1) Journal of International Dispute Settlement (2011) 5, 5. See also, Kaufmann-Kohler, G, "Arbitral Precedent: Dream, Necessity or Excuse? The 2006 Freshfields Lecture", 23(3) Arbitration International (2007) 357, 359; Born, G, International Commercial Arbitration (2nd ed, vol III, Kluwer Law International, Alphen aan den Rijn, 2014), 3810-3817.

80 Lauterpacht, H, The Development of International Law by the International Court (Cambridge University Press, Cambridge, 1982), 13: 'The Court has not committed itself to the view that it is bound to follow its previous decisions even in cases in which it later disagrees with them'.

81 Guillaume, supra nt 79, 5. See also Lauterpacht, supra nt 80, 9-11. For an analysis of the use of precedents in the European Court of Human Rights, see Lupu, Y and Voeten, E, "Precedent in International Courts: A Network Analysis of Case Citations by the European Court of Human Rights", 42(2) British Journal of Political Science (2012) 413. See also Acquaviva, G and Pocar, F, "Stare Decisis" in Max Planck Encyclopedia of Public International Law (online ed, Oxford University Press, 2012).

82 See for instance, Sacerdoti, G, "Precedent in the Settlement of International Economic Disputes: the WTO and Investment Arbitration Models" in Rovine, AW, ed, Contemporary Issues in International Arbitration and Mediation: The Fordham Papers 2010 (Martinus Nijhoff, Leiden, 2011), 225. 
Generally speaking, in international commercial arbitration, confidentiality plays a role suppressing the rise of a precedent doctrine. First, only a few international commercial awards are publicly available. Second, only a few of these awards refer to previous arbitral awards. Third, almost all of the awards that refer to precedents, do so for procedural matters such as objection to jurisdiction, powers of the tribunal to order provisional measures and applicable law. ${ }^{84}$

The issue here is to understand whether the absence of reference to precedents is due to the arbitrators' lack of interest and trust in the stare decisis doctrine or whether this absence is due to some internal elements of the international arbitration system that could be changed. In relation to this topic, arbitration scholars and practitioners can be grouped in three categories. The first category is those who believe a stare decisis doctrine in international arbitration neither exists nor is necessary. ${ }^{85}$ The second category is those authors who, even if they do not exclude the existence of a precedent doctrine in international arbitration, do not recognise its necessity in the field of international commercial law. In particular, Professor Kauffman-Kohler has pointed out that the fact that arbitrators want to maintain their 'freedom to apply the law that allow [them] to 'mint' the rules to take into account the specificities of each case' does not match with the idea of precedent. ${ }^{86}$

The third category strongly supports the idea of precedents in international commercial arbitration. The members of this category have highlighted that, in order to be considered an autonomous system of justice ensuring predictability and certainty, international commercial arbitration needs to accept the role and existence of arbitral precedents. ${ }^{87}$ This means that if a series of arbitral awards is consistent and homogeneous on a specific legal question, these decisions will have 'persuasive authority on arbitrators called upon to decide on the same issue'. ${ }^{88}$ Such a position has been confirmed by commercial arbitral tribunals that were influenced by prior awards between the parties. For instance, in an ICC Award, the arbitral tribunal stated that

83 Reinisch, A, "The Proliferation of International Dispute Settlement Mechanisms: The Threat of Fragmentation vs the Promise of a More Effective System? Some Reflections From the Perspective of Investment Arbitration" in Buffard, I, Crawford, J, Pellet, A and Wittich, S, eds, International Law Between Universalism and Fragmentation (Martinus Nijhoff, Leiden, 2008), 123-124; Reed, L, "The De Facto Precedent Regime in Investment Arbitration: A Case for Proactive Case Management", 25(1) ICSID Review - Foreign Investment Law Journal (2010) 95; Douglas, Z, "Can a Doctrine of Precedent Be Justified in Investment Treaty Arbitration?", 25(1) ICSID Review - Foreign Investment Law Journal (2010) 104; Bjorklund, AK, "Investment Treaty Arbitral Decisions as Jurisprudence Constante" in Picker, CB, Bunn, ID and Arner, DW, eds, International Economic Law: The State and Future of the Discipline (Hart, Oxford, 2008), 265; Schreuer, C and Weiniger, M, "A Doctrine of Precedent?" in Schreuer, C, Ortino, $\mathrm{F}$ and Suchlike, $\mathrm{P}$, eds, Oxford Handbook of International Investment Law (Oxford University Press, Oxford, 2008), 1188; Kaufmann-Kohler, G, "Is Consistency a Myth?" in Banifatemi, Y, ed, Precedent in International Arbitration? (IAI Series on International Arbitration No 5, Juris Publishing, 2008) 137.

84 Kaufmann-Kohler, Arbitral Precedent, supra nt 79, 362-363.

85 Redfern, A, "International Commercial Arbitration: Winning the Battle" in Bender, M, ed, Private Investors Abroad: Problems and Solutions in International Business in 1989 (The Southwestern Legal Foundation, Dallas, 1990), 11-12; Blackaby, N, Partasides, C, Redfern, A and Hunter, M, Redfern and Hunter on International Arbitration (5th ed, Oxford University Press, Oxford, 2009), 577.

86 Kaufmann-Kohler, Arbitral Precedent, supra nt 79, 365 and 375-376.

87 Mourre and Vagenheim, supra nt 62; Born, International Commercial Arbitration, vol III, supra nt 79, 3822.

88 Perret, F, "Is There a Need for Consistency in International Commercial Arbitration?" in Banifatemi, $\mathrm{Y}$, ed, Precedent in International Arbitration, (IAI Series on International Arbitration No 5, Juris Publishing, 2008), 33. 
Enough has been said to show that the [previous] Decision is res judicata as between the ME company and the defendant, but not as between the claimant and the defendant. This does not mean that the [previous] decision can be ignored. Parts of it represent an authoritative ruling on the position of ME country law on certain matters that may be relevant in this case. $^{89}$

In the famous Dow Chemical Award, the arbitral tribunal ruled that

The decisions of these tribunals [ICC arbitral tribunals] progressively create case law which should be taken into account, because it draws conclusions from economic reality and conforms to the needs of international commerce, to which rules specific to international arbitration, themselves successively elaborated, should respond. ${ }^{90}$

If one looks at investment arbitration, the publication of arbitral awards is often considered an essential tool to increase consistency and facilitate development of the law. ${ }^{91}$ In fact, although a general rule on precedents in international investment arbitration does not exist, most arbitral tribunals have recognised the relevance of previous awards or decisions. An analysis of investment cases shows that arbitral tribunals have adopted four different approaches. Some tribunals have clearly stated that no doctrine of precedent exists in international arbitration and that they are not bound by any previous decision. According to this view, each tribunal is constituted ad hoc to decide the case between the parties to the particular dispute. ${ }^{92}$

Other arbitral tribunals have declared that the fact that previous decisions are not binding does not preclude the tribunal from considering arbitral decisions and the arguments of the parties, to the extent that the tribunal may find that they shed any useful

89 Licensor $v$ Licensee, ICC Case No 6363, Final Award, 1991, XVII Yearbook of Commercial Arbitration (1992) 186, 201.

90 Dow Chemical France ia v Isover Saint Gobain, ICC Case No 4131, Interim award, 23 September 1982, IX Yearbook of Commercial Arbitration 131, 136. See also, ICC Case No 7061, Final Award, 28 November 1997 (unpublished, quoted in Born, International Commercial Arbitration, vol II, supra nt 27, 3824):

The arbitration is not bound by the X award; nor are the parties to these arbitration proceedings. There can be no issue estoppel. Nonetheless, it provided a helpful analysis of the common factual background to this dispute. Accordingly, we have borne its findings and conclusions in mind, whilst taking care to reach our own conclusions on the materials submitted by these parties in these proceedings.

91 Ortino, supra nt 21, 133.

92 See, for instance, Methanex Corporation v United States of America, Decision of the Tribunal on Petitioners from Third Persons to Intervene as "Amici Curiae", UNCITRAL, 15 January 2001, para 51; Enron Creditors Recovery Corporation and Ponderosa Assets, LP v Argentine Republic, Decision on Jurisdiction, ICSID Case No ARB/01/3, 14 January 2004, para 40; Bureau Veritas, Inspection Valuation, Assessment and Control, BIVAC BV v Republic of Paraguay, Decision on Jurisdiction, ICSID Case No ARB/07/9, 20 May 2009, para 58; Burlington Resources Inc v Republic of Ecuador, Decision on Jurisdiction, ICSID Case No ARB/08/5, 2 June 2010, para 100; Caratube International Oil Company LLP v Republic of Kazakhstan, Award, ICSID Case No ARB/08/12, 5 June 2012, para 234; Quasar de Valors SIVAC SA et al (Formerly Renta 4 SVSA et al) v Russian Federation, Award, SCC Case No 24/2007, 20 July 2012, para 24; Kilic Insaat Ithalat Sanayi ve Ticaret Anonim Sirketi v Turkmenistan, Award, ICSID Case No ARB/10/1, 2 July 2013, paras 7.1.3 and 7.6.1-7.6.3; Muhammet Cap \& Sehil Insaat Endustri ve Ticaret Ltd Sti v Turkmenistan, Decision on Jurisdiction, ICSID Case No ARB/12/6, 13 February 2015, para 275. 
light on the issues that arise for decision in the case. ${ }^{93}$ Tribunals following this approach seem to consider previous decisions as factual information. ${ }^{94}$

A third category includes tribunals stating that, even though they are not officially bound to follow previous decisions, they should pay due regard to them and explain the reasons leading to eventual departure from previous interpretations. ${ }^{95}$ Finally, some arbitral tribunals have gone further deciding that, even if not bound by previous decisions, they ought to follow solutions established in a series of consistent cases, comparable to the case at hand..$^{96}$

\section{The Issue of Non-Disputing Parties' Submissions (Amicus Curiae Briefs): A Source of Consistency?}

The term amicus curiae refers to 'a person who is not a party to a lawsuit but who petitions the court or is requested by the court to file a brief in the action because that person has a strong interest in the subject matter' ${ }^{97}$ Such petitions are not limited to investment arbitration. All international courts and tribunals have faced requests by non-disputing parties to participate in international proceedings. ${ }^{98}$ While the presence of amicus curiae has not yet generally developed in public international law adjudicatory bodies, ${ }^{99}$

93 See, Fireman's Fund Insurance Company $v$ United Mexican States, Award, ICSID Case No ARB(AF)/02/01, 17 July 2006, para 172; Mohammad Ammar Al-Bahloul v Republic of Tajikistan, Partial Award on Jurisdiction and Liability, SCC Case No V064/2008, 2 September 2009, para 111; Chevron Corporation (USA) and Texaco Petroleum Corporation (USA) v Republic of Ecuador [I], Partial Award on the Merits, PCA Case No AA 277, 30 March 2010, paras 163-164; Liman Caspian Oil BV and NCL Dutch Investment BVv Republic of Kazakhstan, Award, ICSID Case No ARB/07/14, 22 June 2010, paras 172173; RosInvestCo UK Ltd v Russian Federation, Final Award, SCC Case No V079/2005, 12 September 2010, para 285; Yukos Universal Limited (Isle of Man) v Russian Federation, Final Award, PCA Case No AA 227, 18 July 2014, para 1606.

94 See, for instance, Tulip Real Estate and Development Netherlands BV v Republic of Turkey, Decision on Bifurcated Jurisdictional Issue, ICSID Case No ARB/11/28, para 47.

95 See, inter alia, ADC Affiliate Limited and ADC \& ADMC Management Limited v Republic of Hungary, Award, ICSID Case No ARB/03/16, 2 October 2006, para 293; Sociedad Anónima Eduardo Vieira $v$ Republic of Chile, Award, ICSID Case No ARB/04/7, 21 August 2007, paras 223-224; Glamis Gold Ltd v The United States of America, Final Award, UNCITRAL, 8 June 2009, para 8; Crompton (Chemtura) Corp v Government of Canada, Award, UNCITRAL, 2 August 2010, para 109; Daimler Financial Services AG $v$ Argentine Republic, Award, ICSID Case No ARB/05/1, 22 August 2012, para 52; Bosh International, Inc and B\&P Ltd Foreign Investments Enterprise v Ukraine, Award, ICSID Case No ARB/08/11, 25 October 2012, para 211.

96 See, for instance, Duke Energy Electroquil Partners and Electroquil SA v Republic of Ecuador, Award, ICSID Case No ARB/04/19, 18 August 2008, para 117; Saipem SpA v The People's Republic of Bangladesh, Award, ICSID Case No ARB/05/07, 30 June 2009, para 90; Saba Fakes v Republic of Turkey, Award, ICSID Case No ARB/07/20, 14 July 2010, para 96; Jan Oostergetel and Theodora Laurentius $v$ Slovak Republic, Final Award, UNCITRAL, 23 April 2012, para 145; EDF International SA, SAUR International $S A$ and León Participaciones Argentinas SA v Argentine Republic, Award, ICSID Case No ARB/03/23, 11 June 2012, para 897; KT Asia Investment Group BV v Republic of Kazakhstan, Award, ICSID Case No ARB/09/8, 17 October 2013, para 83; Renée Rose Levy and Gremcitel SA v Republic of Peru, Award, ICSID Case No ARB/11/17, 9 January 2015, para 76.

97 Gardner, BA, ed, Black's Law Dictionary (9th ed, West Group, 2006).

98 See, for instance, Sands, PJ and Mackenzie, R, "International Courts and Tribunals, Amicus Curiae" in Max Planck Encyclopedia of Public International Law (Oxford University Press, online ed, 2008).

99 The International Court of Justice (ICJ) allowed a submission by an amicus curiae only once, in an advisory proceeding. See, ICJ, International Status of South-West Africa, Advisory Opinion, ICJ Reports 1950, 11 July 1950. In two following advisory proceedings, the ICJ refused requests to submit information by NGOs: ICJ, Legal Consequences for States of the Continued Presence of South Africa in Namibia 
submissions have become frequent in the last two decades in WTO law ${ }^{100}$ and in international investment arbitration. ${ }^{101}$ This is mostly due to the close relationship between economic and commercial interests on the one hand and the public interest on the other.

Traditionally, in international investment arbitration, amicus curiae briefs have been submitted by a non-governmental organisation (NGO) 'active in the area of human rights or the environment that has an interest in a dispute that gives rise to issues of human rights or the environment'. ${ }^{102}$ However, over time, the nature of the submitting parties has changed and it is no longer limited to public interest advocacy groups. ${ }^{103}$ A nondisputing State (home State) can also submit petitions sua sponte or at the request of the arbitral tribunal, in particular when interpretation of a treaty provision is questioned.

In the paragraphs below, the pros and the cons of the latter type of 'friends of the court' submissions in investment arbitration are scrutinised. ${ }^{104}$

(South West Africa) notwithstanding Security Council Resolution 276 (1970), Advisory Opinion, ICJ Reports 1971, 21 June 1971; ICJ, Legality of the Use by a State of Nuclear Weapons in Armed Conflict, Advisory Opinion, ICJ Reports 1996, 8 July 1996. As for the International Tribunal for the Law of the Sea (ITLOS), see ITLOS, Reponsibilities and Obligations of States Sponsoring Persons and Entities with Respect to Activities in the Area, Advisory Opinion, ITLOS Reports 2011, 1 February 2011. See also, ITLOS, The "Arctic Sunrise" Case (Kingdom of the Netherlands v Russian Federation), Order on the Request for the Prescription of Provisional Measures, ITLOS Case No 22, 22 November 2013.

100 See, for instance, Stern, B, "The Emergence of Non-State Actors in International Commercial Disputes Through WTO Appellate Body Case-Law" in Sacerdoti, G, Yanovich, A and Bohanes, J, eds, The WTO at Ten: The Contribution of the Dispute Settlement System (Cambridge University Press, Cambridge, 2006), 372.

${ }^{101}$ See, for instance, Stern, B, "Civil Society's Voice in the Settlement of International Economic Disputes", 22(2) ICSID Review - Foreign Investment Law Journal (2007) 280; Obadia, E, "Extension of Proceedings Beyond the Original Parties: Non-Disputing Party Participation in Investment Arbitration", 22(2) ICSID Review - Foreign Investment Law Journal (2007) 349; Grisel, F and Vinuales, JE, "L'Amicus Curiae dans l'Arbitrage d'Investissement", 22(2) ICSID Review - Foreign Investment Law Journal (2007) 380.

${ }^{102}$ Kaufmann-Kohler, G, "Non-Disputing State Submissions in Investment Arbitration: Resurgence of Diplomatic Protection" in Boisson de Chazournes, L, Kohen, MG and Viñuales, JE, eds, Diplomatic and Judicial Means of Dispute Settlement (Martinus Nijhoff Publishers, Leiden, 2012), 312.

${ }^{103}$ Levine, E, "Amicus Curiae in International Investment Arbitration: The Implications of an Increase in Third-Party Participation", 29(1) Berkeley Journal of International Law (2011) 200, 212.

104 There is another kind of intervention from third-party States in international adjudication. For instance, Article 62 of the ICJ Statute allows intervention of a third State that 'has an interest of a legal nature which may be affected by the decision of the case'. The Court denied requests to intervene pursuant to Article 62 in some cases: see, for instance, ICJ, Continental Shelf (Tunisia v Libyan Arab Jamahiriya), Judgment on the Application for Permission to Intervene by the Government of Malta, ICJ Reports 1981, 14 April 1981; a Chamber of the Court permitted a limited intervention by Nicaragua in a maritime aspect in the case ICJ, Land, Island and Maritime Frontier Dispute (El Salvador v Honduras), Judgment on the Application for Permission to Intervene by Nicaragua, ICJ Reports 1990, 13 September 1990. The full Court also permitted a limited intervention by Equatorial Guinea in the case ICJ, Land and Maritime Boundary between Cameroon and Nigeria (Cameroon v Nigeria), Order on the Intervention from the Republic of Equatorial Guinea, ICJ Reports 1999, 21 October 1999. In investment arbitration similar cases exist. For instance, in NAFTA arbitrations, interventions by a third State that is neither the host State nor the home State are common (see, for instance, Mesa Power Group, LLC v Government of Canada, Submission of Mexico Pursuant to NAFTA Article 1128, UNCITRAL, PCA Case No 2012-17, 25 July 2014). In ICSID arbitrations, an exemplary case is Siemens AG v Argentine Republic, Annulment Proceeding, Letter from Lisa J Grosh to Claudia Frutos-Peterson, ICSID No ARB/02/8, 1 May 2008. In that case, the United States, although not party to the BIT under which the dispute was brought, felt the necessity to intervene to protect US investors in connected cases. 


\section{IV.1. Home States' Amicus Curiae Submissions as Interpretative Tools: Some Examples From International Investment Arbitral Awards}

The practice of submissions from the home State in international investment cases is not new. In the 1983 rules of the Iran-United States Claims Tribunal, a provision allowing submission by the non-disputing State already existed. ${ }^{105}$ Similar provisions are included in the North American Free Trade Agreement (NAFTA), ${ }^{106}$ the 2012 US Model BIT, ${ }^{107}$ the 2004 Canadian Model BIT, ${ }^{108}$ as well as several Free Trade Agreements (FTAs) concluded by the US and Canada. ${ }^{109}$

Due to the importance of the issue, after the 2006 Amendment, the ICSID Arbitration Rules include an article dealing with submissions by non-disputing parties. Article 37(2) reads as follows:

After consulting both parties, the Tribunal may allow a person or entity that is not a party to the dispute (in this Rule called the "nondisputing party") to file a written submission with the Tribunal regarding a matter within the scope of the dispute. ${ }^{110}$

The wording 'person or entity; should be broadly interpreted to encompass 'a natural person, a juridical person, an unincorporated NGO or a State'. ${ }^{111}$ In the NAFTA context, the home State filed several submissions concerning interpretation of the investment provisions of the treaty. For instance, in Marvin Feldman v Mexico, the United States submitted an amicus curiae brief to support its national investor and interpreted Article 1117(1) of NAFTA in a broad way, stating that this provision did not bar a claim brought by a natural person who was a citizen of the United States and a permanent resident of Mexico. ${ }^{112}$ In another NAFTA case, Matalclad Corporation $v$ Mexico, the foreign investor was a US citizen. The United States intervened in the proceedings by expressing its views on several aspects, including the NAFTA regime covering local governments and municipalities and the definition of the term "tantamount to expropriation". ${ }^{113}$ In a more recent case, Mesa Power Group v Canada, the United States submitted a brief dealing with

105 Iran-United States Claims Tribunal, Rules of Procedure, Notes to Article 15, para 5:

The arbitral tribunal may, having satisfied itself that the statement of one of the two Governments - or, under special circumstances, any other person - who is not an arbitrating party in a particular case is likely to assist the tribunal in carrying out its task, permit such Government or person to assist the tribunal by presenting oral or written statements.

106 Article 1128, NAFTA. See also the Statement of Non-Disputing Party Participation of the NAFTA Free Trade Commission of 7 October 2003.

107 Article 28(2), US Model Bilateral Investment Treaty (2012) (US Model BIT).

108 Article 35, Canada Model Foreign Investment Protection Agreement (2004) (Canada Model FIPA) or (Canada Model BIT).

109 For the US, see, for instance, Article 10.20.2, Central American Free Trade Agreement (FTA) (2004). For Canada, see, Article X.35, Comprehensive Economic and Trade Agreement (CETA).

110 Article 37(2), ICSID, ICSID Arbitration Rules (2006) (ICSID Arbitration Rules).

111 Antonietti, A, "The 2006 Amendments to the ICSID Rules and Regulations and the Additional Facility Rules", 21(2) ICSID Review - Foreign Investment Law Journal (2006) 427, 435.

112 Marvin Roy Feldman Karpa v United Mexican States, Submission of the United States of America on Preliminary Issues, ICSID Case No ARB(AF)/99/1, 6 October 2000, paras 2-12.

113 Metalclad Corporation $v$ United Mexican States, Submission of the Government of the United States, ICSID Case No ARB(AF)/97/1, 9 November 1999, paras 3-9. 
interpretation of several NAFTA standards of treatment, including the minimum standard of treatment and national treatment. ${ }^{114}$

In disputes under bilateral investment treaties, home State submissions are less frequent. Also, the non-disputing State does not often file amicus curiae submissions sua sponte, but is usually invited to express its views by the arbitral tribunal. For instance, in Aguas del Tunari v Bolivia, the Tribunal requested that the Government of the Netherlands submit documents concerning comments it had made before the Dutch parliament relating to jurisdiction issues under the Netherland-Bolivia Bilateral Investment Treaty (BIT) applicable to the dispute. ${ }^{115}$ In Eureko v Slovak Republic, the Dutch Ministry of Economic Affairs was invited by the arbitral tribunal to express its position on the tribunal's jurisdiction. ${ }^{116}$ The Dutch Government provided observations and attached a letter received by the Slovak Ministry of Foreign Affairs bearing on the alleged termination of the BIT. Although helpful, the arbitral tribunal considered its submissions unnecessary. ${ }^{117}$

In $S G S v$ Pakistan, the home State took the initiative to intervene without being invited by the arbitral tribunal. Switzerland wrote to ICSID noting that the arbitral tribunal's interpretation of the umbrella clause was too narrow and did not reflect the intention of the BIT's contracting parties at the time the treaty was concluded. The Swiss Government, as home State, complained that the arbitral tribunal should have consulted both States before issuing its interpretation. ${ }^{118}$ However, as the Swiss Government sent the letter after the decision of jurisdiction was rendered, the submission did not have any impact on the final decision.

\section{IV.2. The Role of the UNCITRAL Rules on Transparency in Framing the Home-State Submissions}

Since 2008, the UNCITRAL has officially recognised the relevance of ensuring transparency in investor-State dispute resolution. ${ }^{119}$ There were three forms of transparency discussed by UNCITRAL Member States, namely a model clause for inclusion in the IIAs' ISDS, specific arbitration rules and guidelines for States, arbitrators and parties involved. ${ }^{120}$ Delegations supported the idea of including legal standards on transparency as a supplement to the UNCITRAL Arbitration Rules, ${ }^{121}$ 'in the form of

${ }^{114}$ Mesa Power Group LLC $v$ Government of Canada, Submission of the United States of America, UNCITRAL, PCA Case No 2012-17, 25 July 2014, paras 5-15. See also Detroit International Bridge Company $v$ Government of Canada, Submission of the United States of America, PCA Case No 2012-25, 14 February 2014.

115 ICSID, Aguas del Tunari v Bolivia, Decision on Respondent's Objections to Jurisdiction, ICSID Case No $\mathrm{ARB} / 02 / 3,21$ October 2005, para 258.

116 Eureko BB v The Slovak Republic, Award on Jurisdiction, Admissibility and Suspension, PCA Case No 2008-13, 26 October 2010, paras 154-174.

117 Eureko BB v The Slovak Republic, paras 155-163 and 217-219.

118 Société Générale de Surveillance SS v Islamic Republic of Pakistan, Note in Interpretation of Article 11 of the Bilateral Investment Treaty between Switzerland and Pakistan in the light of the Decision of the Tribunal on Objections to Jurisdiction, ICSID Case No ARB/01/13, 1 October 2003.

119 UNCITRAL, Report of United Nations Commission on International Trade Law, 16 June-3 July 2008, (Forty-First Session), A/63/17, para 314.

120 UNCITRAL, Note by the Secretariat: Settlement of commercial disputes: Preparation of rules of uniform law on transparency in treaty-based investor-State dispute settlement, 5 August 2010, A/CN9/WGII/WP160/Add 1, 5 August 2010, paras 22-31.

121 UNCITRAL, REPORT: Settlement of commercial disputes: preparation of a legal standard on transparency in treaty-based investor-State arbitration, Working Group II (Arbitration and Conciliation) of the work of its fifty-third session (Vienna, 4-8 October 2010), A/CN9/712, 20 October 2010, para 76. 
clear rules rather than looser and more discursive guidelines' ${ }^{122}$ UNCITRAL adopted the Rules on Transparency ${ }^{123}$ that require disclosure of a wide range of information submitted to and issued by the tribunals, and facilitate participation by amicus curiae and non-disputing State parties.

Unlike ICSID Arbitration Rules, the travaux préparatoires of the UNCITRAL Transparency Rules show that delegations discussed the possibility of dealing separately with each type of submission by non-disputing parties.

It was observed that two possible types of amicus curiae should be distinguished and perhaps considered differently. The first type could be any third party that would have an interest in contributing to the solution of the dispute. A second type could be another State party to the investment treaty at issue that was not a party to the dispute. It was noted that such State often had important information to provide, such as information on travaux préparatoires, thus preventing one-sided treaty interpretation. In response, it was said that an intervention by a nondisputing State, of which the investor was a national, could raise issues of diplomatic protection and was to be given careful consideration. It was suggested that third parties who could contribute to the resolution of the dispute could be identified and invited by the arbitral tribunal to assist it. The home State of the investor could be one such third party. ${ }^{124}$

At the fifty-third session of the Working Group, it was observed that a State Party to the investment treaty that was not a party to the dispute could also wish to be invited, or have a treaty right to make submissions. It was noted that such State(s) often had important information to provide, such as information on the travaux préparatoires, thus preventing one-sided treaty interpretation. ${ }^{125}$

Thus, in order to contribute to clarifying the legal regime applicable to the two categories of submissions and to mark the differences, ${ }^{126}$ two different articles were included in the UNCITRAL Transparency Rules: Article 4, dealing with submissions by third persons; and Article 5, regulating submissions by a non-disputing Party to the treaty. For the purpose of this paper, the analysis will only focus on Article 5.

122 UNCITRAL, Report of Working Group II (Arbitration and Conciliation) on the Work of its Fifty-fourth Session, (New York, 7-11 February 2011), A/CN 9/717, 25 February 2011, para 26.

123 UNCITRAL, Report of United Nations Commission on International Trade Law (Forty-Sixth Session, 8-26 July 2013), A/68/17, para 128; UNCITRAL, UNCITRAL Rules on Transparency in Treaty-based Investor-State Arbitration, effective 1 April 2014 (UNCITRAL Transparency Rules).

124 UNCITRAL, REPORT: Settlement of commercial disputes: preparation of a legal standard on transparency in treaty-based investor-State arbitration, Working Group II (Arbitration and Conciliation) of the work of its fifty-third session (Vienna, 4-8 October 2010), A/CN9/712, 20 October 2010, para 49 [emphasis added].

125 UNCITRAL, Report of Working Group II (Arbitration and Conciliation) on the Work of its Fifty-fifth Session (Vienna, 3-7 October 2011), A/CN 9/736, 17 October 2011, para 78.

$126 I d$, para 83. 


\section{IV.3. Positive and Negative Impacts of Article 5(1) of the UNCITRAL Transparency Rules}

Article 5(1) states that 'the arbitral tribunal shall, subject to paragraph 4, allow, or, after consultation with the disputing parties, may invite, submissions on issues of treaty interpretation from a non-disputing Party to the treaty'. This provision has been subject to several debates comparing its pros and cons.

As acknowledged in the UNCITRAL's Working Group II report, an element supporting the home-State submissions in investment arbitral proceedings is the fact that the State party to the IIA 'might bring a perspective on the interpretation of the treaty, including access to the travaux préparatoires which might not be otherwise available to the tribunal, thus avoiding one-sided interpretations limited to the respondent State's contentions'. ${ }^{127}$ Furthermore, acceptance of submissions from the home State would ensure that balanced and comprehensive information would be provided to the arbitral tribunal, ${ }^{128}$ thus enhancing transparency in investment arbitration. ${ }^{129}$

Finally, the tool of amicus curiae used by the home State has been described as less problematic than a State-to-State arbitration or litigation because it would provide 'the authentic view of the home state as to the contracting parties' intention, supported by contemporaneous documentation and/or witness testimony' ${ }^{130}$ without the need of initiating another proceeding that would run parallel to the investor-State arbitration. The State-to-State arbitration provision is contained in most bilateral investment treaties and multilateral agreements. ${ }^{131}$ Such arbitrations usually address issues of application and interpretation of treaty provisions, ${ }^{132}$ but they have also included claims of diplomatic protection. ${ }^{133}$ Compared to the submission of an amicus curiae brief, a State-to-State

$127 I d$, para 86.

128 UNCITRAL, Report of Working Group II (Arbitration and Conciliation) on the Work of its Fifty-eighth Session (New York, 4-8 February 2013), A/CN 9/765, 13 February 2013, para 44.

129 Transparency in international arbitration has been described as a set of concepts such as public access, procedural transparency, as well as the governmental obligation to disclose information. See, for instance, Bjorklund, AK, "The Promise and Peril of Arbitral Precedents: The Case of Amici Curiae" in Hoffman AK, ed, Protection of Foreign Investment Through Modern Treaty Arbitration - Diversity and Harmonization (ASA Special Series No 34, 2010) 165, 175.

130 Banifatemi, Consistency in the Interpretation of Substantive Investment Rules, supra nt 5, 200.

131 See, for instance, Article 10, French Model BIT (2006); Article 37, US Model BIT; Article 9, Italian Model BIT (2003); Article 27, Energy Charter Treaty (1995) 2080 UNTS 95.

132 See, for instance, Peru $v$ Chile mentioned in Award, Empresas Lucchetti, SA and Lucchetti Peru, SAv Republic of Peru, ICSID Case No ARB/03/04, 7 February 2005, para 7: Peru brought an arbitration claim in response to an earlier-initiated investor-state claim brought by the Chilean investor, Lucchetti, against Peru. The State-to-State arbitration was ostensibly designed to resolve a disagreement between Peru and Chile as to the proper interpretation of the Peru-Chile BIT. However, the State-to-State arbitration appears to have been abandoned after arbitrators in the separate Lucchetti v Peru investorState case declined to suspend their own proceedings so that the State-to-State proceeding could be pursued; Republic of Ecuador $v$ United States of America, PCA Case No 2012-5, Award, 29 September 2012. See, Roberts, A, "State-to-State Investment Treaty Arbitration: A Hybrid Theory of Interdependent Rights and Shared Interpretive Authority", 55(1) Harvard Journal of International Law (2014) 1; Potestà, M, "State-to-State Dispute Settlement Pursuant to Bilateral Investment Treaties: Is there Potential?" in Boschiero, N, Scovazzi, T, Pitea, C and Ragni, C, eds, International Courts and the Development of International Law: Essays in Honour of Tullio Treves (TMC Asser Press, The Hague, 2013), 753.

133 See, for instance, Republic of Italy v Republic of Cuba, Ad-Hoc Arbitration, Final Award, 15 January 2008 : Italy brought a claim on behalf of itself and several Italian investors alleging violations of the Cuba-Italy $B I T$. Italy contended that it had 'double standing' to bring a direct claim to vindicate its own substantive 
proceeding might raise at least three issues. First, political and diplomatic consequences might be detrimental to the economic and commercial relations of the State parties to the treaty. Second, in the context of the same investment dispute, it might be possible that a State-to-State arbitration and an investor-State arbitration run in parallel. The question here is whether the investor-State arbitration proceedings should be postponed until the State-to-State dispute is resolved. Third, one should take into consideration the value of a decision in a State-to-State arbitration for future international investment arbitrations arising out of the same treaty. ${ }^{134}$

Although the UNCITRAL provision of home-State submissions in investor-State arbitrations has been generally positively received, some doubts have been expressed. First of all, during the negotiations of the UNCITRAL Transparency Rules, some delegations challenged the usefulness of such a provision. In particular, 'it was said that non-disputing State(s) Party(ies) to a treaty enjoyed the right to comment on the treaty, or arbitral tribunals might request submissions'. ${ }^{135}$ Moreover, the issue of diplomatic protection might be at stake, ${ }^{136}$ especially if the home-State has the opportunity to file submissions addressing legal and factual matters beyond those of treaty interpretation. ${ }^{137}$ Finally, home-State submissions are limited to a specific treaty and do not influence other

rights and a diplomatic protection claim to vindicate the rights of Italian nationals that had invested in Cuba. Cuba argued that the existence of an investor-State arbitration clause in the treaty prevented Italy from bringing a diplomatic protection claim. The tribunal rejected Cuba's argument but ultimately held that Italy's direct claim failed because its claim on behalf of its nationals failed.

134 See, for instance, CME v The Czech Republic, UNCITRAL, Final Award, 14 March 2003, paras 87-93. In this case, the Czech Republic requested consultations with the Netherlands to resolve certain issues of interpretation and application of the treaty arising from the Tribunal's partial award. The two contracting States issued 'agreed minutes' that the arbitral tribunal took into account to render its final award. Contradictory views have been provided by scholars. For instance, Professor Amerasinghe stated that

it cannot be denied that there is a 'two-track' system under the BIT. However, it does not mean that the system established under Article VII cannot overlap with, influence and take precedence over the system established under Article VI. Indeed, it seems highly probable and logical that Article VII was included so that any interpretation under Article VII would have to be respected by investor-State arbitral tribunals,

Republic of Ecuador v United States of America, PCA Case No 2012-5, Expert Opinion of Professor Amerasinghe J, CF, 29 September 2012, para 28. In contrast, Professor Reisman expressed that 'a decision emanating from a procedure such as that proposed by Ecuador or from the decision of this Tribunal would not be binding on tribunals exercising jurisdiction under the Article VI investor-State track. Nor would it be an amendment to the BIT': Republic of Ecuador v United States of America, PCA Case No 2012-5, Expert Opinion of Professor Reisman, MW, 25 April 2012, paras 57-58.

135 UNCITRAL, Report of Working Group II (Arbitration and Conciliation) on the Work of its Fifty-fifth Session (Vienna, 3-7 October 2011), A/CN 9/736, 17 October 2011, para 81.

136 See, in general, Amerasinghe, CF, Diplomatic Protection (Oxford University Press, New York, 2008); Juratowitch, B, "The Relationship between Diplomatic Protection and Investment Treaties", 23(1) ICSID Review - Foreign Investment Law Journal (2008) 10; Dugard, J, "Diplomatic Protection", in, Max Planck Encyclopedia of Public International Law (online ed, 2009), at <opil.ouplaw.com/view/10.1093/law:epil/9780199231690/law-9780199231690-e1028?prd=EPIL> (accessed 7 May 2015); Schreuer, C, "Investment Protection and International Relations" in Reinisch, A and Kriebaum, U, The Law of International Relations: Liber Amicorum Hanspeter Neuhold (Eleven International Publishing, Den Haag, 2007), 345; Sacerdoti, G, "Barcelona Traction Revisited: Foreignowned and Controlled Companies in International Law" in Dinstein, Y, International Law at a Time of Perplexity: Essays in Honour of Shabtai Rosenne (Martinus Nijhoff Publishers, Dordrecht, 1989), 699.

137 UNCITRAL, Report of Working Group II (Arbitration and Conciliation) on the Work of its Fifty-fifth Session (Vienna, 3-7 October 2011), A/CN 9/736, 17 October 2011, para 87. See, also, Kaufmann-Kohler, Non-Disputing State Submissions, supra nt 102, 305-319. 
investment agreements, as a result, consistency would be achieved only in respect of a single treaty. ${ }^{138}$

As a general matter, due to the ad hoc character of international arbitration, the access of non-disputing parties to arbitration proceedings should not be systematic and unlimited. ${ }^{139}$ The issue of how to regulate such submissions is a topical one. How have the UNCITRAL Transparency Rules allowed the filling of this gap between positive and negative impacts of home-State submissions?

During the negotiations for the Transparency Rules, the UNCITRAL Working Group II decided to proceed by addressing the concern that guidance should be provided with respect to submission by third parties. ${ }^{140}$ Article 5 provides for clear rules establishing that, as for issues of treaty interpretation, the arbitral tribunal shall ensure that: 1 . submissions do not disrupt, unduly burden the arbitral proceedings or unfairly prejudice the disputing parties; ${ }^{141}$ and 2 . disputing parties have a reasonable opportunity to react to the submissions. ${ }^{142}$

According to Article 5(2), the requirements for home-State's submissions become stricter when such submissions deal with factual or legal matters beyond treaty interpretation. In this case, beyond Articles 5(4) and 5(5), the requirement of Article 4(3) dealing with third-persons amicus curiae is applicable. In accordance with this provision, the arbitral tribunal shall consider: 1 . the significant interest of the home-State in the arbitral proceedings; and 2. the value of the submission for the determination of the factual or legal matter. ${ }^{143}$

\section{The Increasing Codification of Transparency Rules: the US and Canadian Traditions}

Recent investment treaty negotiations show that, in addition to the traditional provisions, some States have codified new standards of transparency that have traditionally been absent in IIAs. This ambitious 'treatification' ${ }^{144}$ can be explained in part by the need for the parties to take into account multiple interests of the negotiating States, their civil societies and the business actors involved. An attempt to balance all these interests is the 1998 Organisation for Economic Co-operation and Development (OECD) Multilateral Agreement on Investment (MAI) whose negotiations failed for several reasons.

In particular, the MAI's failure was mostly due to the fact that most investment rules are customary in nature and thus subject to competing interpretations by parties representing different interests. ${ }^{145}$ For this reason, even since the first BIT between Germany and Pakistan in 1959, it has been easier for States to negotiate bilateral instruments rather than multilateral agreements on investment matters. The spread of

138 Banifatemi, Consistency in the Interpretation of Substantive Investment Rules, supra nt 5, $200-225$.

139 Banifatemi, Mapping the Future of Investment Treaty Arbitration, supra nt 22, 323-324.

140 UNCITRAL, Report of Working Group II (Arbitration and Conciliation) on the Work of its Fifty-fifth Session (Vienna, 3-7 October 2011), A/CN 9/736, 17 October 2011, para 70.

141 Article 5(4), UNCITRAL Transparency Rules.

142 Article 5(5), UNCITRAL Transparency Rules.

143 Article 4(3), UNCITRAL Transparency Rules.

144 Salacuse, JW, "The Treatification of International Investment Law: A Victory of Form Over Life? A Crossroads Crossed?", 3(3) Transnational Dispute Management (2006) 20.

145 Meyer, T, “Codifying Custom”, 160 University of Pennsylvania Law Review (2012) 995, 1054. 
bilateral IIAs with various codified standards has made the development of a multilateral investment agreement almost impossible to achieve. ${ }^{146}$

Until the beginning of the 2000s, standards included in the IIAs have been broadly drafted, thus being open to different and diverging interpretations by the arbitral tribunals. Afterwards, parties to IIAs felt the need to establish standards that are complete, clear and specific, uncontestable and enforceable. ${ }^{147}$ Since the entry into force of the NAFTA in 2001 and the drafting of the Canadian and US Model BITs in 2004, new and more accurate standards of investment protection are today codified in modern IIAs. Examples of this new approach are inter alia the inclusion of the 'right to regulate' provisions ${ }^{148}$ and the transparency standards in the IIAs. In particular, transparency standards are either drafted in detailed terms ${ }^{149}$ or they refer to existing external instruments, such as the UNCITRAL Transparency Rules. ${ }^{150}$

The concept of transparency standards in investment arbitration has North American origins, as both Canada and the United States have adopted strong policies promoting transparency. ${ }^{151}$ For instance, in July 2001, the three NAFTA member States issued a note stating that nothing in the NAFTA: 1 . imposes a general duty of confidentiality on the disputing parties to an investment arbitration; and 2. precludes the Parties from providing public access to documents submitted to, or issued by, an investment tribunal. ${ }^{152}$ Two years later, two other important statements from NAFTA members confirmed the relevance of transparency in investor-State arbitrations. In the first statement, the Free Trade Commission stated that no NAFTA provision limits a Tribunal's discretion to accept written submissions from a person or entity that is not a disputing party and established clear rules concerning the procedure for such submissions. ${ }^{153}$ In a second set of statements, the United States and Canada expressed their commitment to have public hearings in proceedings commenced under Chapter 11 of the NAFTA. ${ }^{154}$

Following the NAFTA policy towards greater transparency in international arbitration, transparency has also been incorporated in the Model BITs of Canada and the United States as a fundamental principle. First, both models include provisions concerning transparency of arbitration proceedings stating that each party is obliged to share with the other party all information concerning law, regulations, procedures and administrative rulings. ${ }^{155}$ Second, based on Article 1128 of the NAFTA, the two models

$146 I d, 1065$.

147 Salacuse, JW, The Three Laws of International Investment (Oxford University Press, New York, 2013), 331.

148 Titi, A, The Right to Regulate in International Investment Law (Studies in International Investment Law vol 10, Nomos/Hart Publishing, Baden-Baden, 2014), 256.

149 For instance, the provisions on transparency contained in the US and Canadian Model BITs, briefly analysed below.

150 See, Article X.33, EU-Canada Comprehensive and Economic Trade Agreement (CETA).

151 Caplan, LM and Sharpe, JK, "United States" in Brown, C, ed, Commentaries on Selected Model Investment Treaties (Oxford University Press, Oxford, 2013) 755, 838. Although the reference is to the US policy, the same can be said about Canada.

152 NAFTA Free Trade Commission, Note on Interpretation of Certain Chapter 11 Provisions, 31 July 2001.

153 NAFTA Free Trade Commission, Statement on Non-Disputing Party Participation, 7 October 2003.

154 US and Canada, Statementon Open Hearings in NAFTA Chapter Eleven Arbitrations, 7 October 2003, at <ustr.gov/archive/assets/Trade_Agreements/Regional/NAFTA/asset_upload_file143_3602.pdf> (accessed 20 May 2015) and <international.gc.ca/trade-agreements-accords-commerciaux/agr-acc/naftaalena/open-hearing.aspx?lang=en $>$ (accessed 20 May 2015), respectively.

155 Article 19(1), Canada Model FIPA; Articles 10-11, US Model BIT. 
provide the possibility for the non-disputing party to make submissions to the tribunal on a question of interpretation of the treaty. ${ }^{156}$ The Canadian Model BIT goes even further than NAFTA, giving the right to the non-disputing party to attend any hearings. ${ }^{157}$

The US and Canadian intention to contribute towards increasing transparency in international arbitration is also supported by the fact that the two States have agreed not to apply confidentiality to the LCIA arbitration proceedings relating to the 2006 Softwood Lumber Agreement ${ }^{158}$ which provided for all documents to be made public unless the Tribunal issued particular confidentiality orders. ${ }^{159}$ The heart of the CanadaUnited States softwood lumber dispute is the US claim that the Canadian lumber industry was unfairly subsidised by federal and provincial governments and that the prices charged to harvest the timber were set administratively, rather than through the competitive marketplace.

Although the US and Canada agreed in the Agreement to submit their disputes to an arbitral tribunal constituted under the LCIA Arbitration Rules (designed to administer commercial disputes between private parties under strict confidentiality), they opted for a more transparent policy. In particular, due to the serious impact of the dispute on both the US and Canadian economies and civil societies, the two governments decided to make public the pleadings, transcripts, awards and other documents available, as well as to open the hearings to the public. ${ }^{160}$

\section{What is Next: Will Transparency in Investment Arbitration Become a Global Value?}

In 2013, the UNCITRAL Working Group II was entrusted with the task of preparing a Convention on the implementation of the Rules on Transparency to investment treaties existing before 1 April 2014, applicable regardless of the arbitration rules selected by an investor under a relevant investment treaty. ${ }^{161}$ The United Nations Convention on Transparency in Treaty-based Investor-State Arbitration was adopted by the General Assembly on 10 December 2014 and was opened for signature in Port Luis, Mauritius, on 17 March 2015. ${ }^{162}$

As mentioned in the previous paragraphs, the US and Canada have been the pioneers of the development of transparency in international investment law both in multilateral fora (for example, NAFTA) and in their bilateral investment and commercial relations (BITs and FTAs). However, transparency has become a priority of the investment

156 Article 35(1), Canada Model FIPA; Articles 28(2), US Model BIT. Both models provide also for submissions from third persons (ie the traditional amicus curiae) at Article 39, Canada Model FIPA and 28(3) US Model BIT.

157 Article 35(2), Canada Model FIPA.

158 United States of American v Canada, Final Award, LCIA Case No 111790, 25 July 2012, at <ustr.gov/sites/default/files/LCIA\%20111790\%20Award\%20of\%20the\%20Tribunal.pdf> (accessed 20 May 2015).

159 See, the Softwood Lumber Agreement between the Government of Canada and the Government of the United States of America of 12 September 2006, at <international.gc.ca/controls-controles/softwoodbois_oeuvre/other-autres/agreement-accord.aspx?lang=eng> (accessed 20 May 2015) (the Agreement).

160 See Article XIV(17) and (18), the Agreement.

161 See UNCITRAL, Report of Working Group II (Arbitration and Conciliation) on the Work of its Fifty-ninth Session (Vienna, 16-20 September 2013), A/CN 9/794, 26 September 2013, paras 3 and 32.

162 As of 24 April 2015, ten States have signed the Convention (Canada, Finland, France, Germany, Mauritius, Sweden, Switzerland, Syrian Arab Republic, United Kingdom, and United States of America). 
agendas of other important actors in international trade. For instance, the Australia-Chile FTA of 2009 includes many transparency standards such as: 1. the possibility for the nondisputing party and third persons to make an amicus curiae submission; ${ }^{163} 2$. the publication of pleadings, memorials, transcripts of hearings, orders, awards and decisions of the tribunals; ${ }^{164}$ and 3 . the exchanges of regulatory, legislative and administrative information between the parties. ${ }^{165}$

The European Union (EU) has also changed its investment policy, trying to improve the system with the inclusion of transparency standards in its BITs and FTAs. ${ }^{166}$ This interest toward transparency is particularly apparent since the negotiations of trade and investment agreements between EU and Canada and the United States have started. For instance, the European Commission stated that the Comprehensive Economic and Trade Agreement (CETA) reflected a 'turning point in the European approach to investment policy'167 and recognised that 'of the 3000 agreements with ISDS in existence, only the ones to which the United States and Canada are party to have transparency arrangements'. ${ }^{168}$ A comparison between FTAs already concluded by the European Union and a third State and FTAs currently under negotiation shows that the EU's willingness to foster transparency in international investment relations is strong. ${ }^{169}$

To this extent, the provisions included in the CETA with Canada are exemplary. The consolidated text includes provisions directly referring to the UNCITRAL Transparency Rules, ${ }^{170}$ requires parties to hold open hearings, ${ }^{171}$ to share information relevant to the arbitration proceedings ${ }^{172}$ and allows the non-disputing party submissions on interpretation of the treaty as well as third persons' amicus curiae submissions on matters falling within the scope of the dispute. ${ }^{173}$ Although the EU-US Transatlantic Trade and Investment Partnership (TTIP) under negotiation between the European Union and the United States has been subject to several criticisms, one must admit that the transparency provisions provided for by the treaty are complete and more advanced than those included in previous BITs and FTAs concluded by the European Union. As for CETA, non-disputing parties' submissions and third persons' amicus curiae are permitted, ${ }^{174}$ all documents relating to all steps of the arbitration proceedings (from the notice of intent to the final award) are to be made publicly available, ${ }^{175}$ and hearings are open to public. ${ }^{176}$

163 Article 10.21(2) and 10.20(2), Australia-Chile FTA (2009) (Australia-Chile FTA).

164 Article 10.22(1) and (2), Australia-Chile FTA.

165 Article 11.24, Australia-Chile FTA.

166 See European Commission, Investment Protection and Investor-to-State Dispute Settlement in EU agreements. Executive Summary: A New Start of Investment and Investment Protection, November 2013, at <trade.ec.europa.eu/doclib/docs/2013/november/tradoc_151916.pdf.> (accessed 20 May 2015), 1.

167 See European Commission, Investment Provisions in the EU-Canada Free Trade Agreement (CETA), 26 September 2014, at <trade.ec.europa.eu/doclib/docs/2013/november/tradoc_151918.pdf> (accessed 20 May 2015), 1.

$168 I d, 4$.

169 See European Commission, Overview of Free Trade Agreements, at <ec.europa.eu/trade/policy/accessingmarkets/investment/> (accessed 20 May 2015).

170 Article X.33, CETA.

171 Article X.33, CETA.

172 Article X.34, CETA.

173 Article X.35, CETA.

174 Article 11.22, TTIP.

175 Article 11.22, TTIP.

176 Article 11.22, TTIP. 
To conclude, it is fair to say that international investment law and arbitration have been witnessing positive developments concerning transparency. Current investment practices show that, generally, governments with mature civil societies able to impose their voices and interests on IIA negotiations are those that are more ready to foster transparency in the international investment system. Therefore, it is not surprising that very detailed, transparency-orientated provisions are incorporated in the IIAs concluded by countries such as Canada, the US, Australia as well as the European Union, where different interest groups (for example, NGOs) are involved in all steps of IIA negotiations. It is worth mentioning that, before foreign direct investments fell within the scope of the EU common commercial policy, ${ }^{177}$ the IIAs concluded by Member States even those that are important actors in the global investment flows - did not include specific and detailed provisions on transparency of the investor-State dispute settlement mechanisms. ${ }^{178}$ After the entry into force of the Lisbon Treaty, the European Union has been playing a significant role by subjecting its Member States to the transparency requirements in investment arbitral proceedings.

www.grojil.org

177 Foreign direct investments are part of the EU Common Commercial Policy since the entry into force of the Treaty of Lisbon, on 1 December 2009. See Articles 3 and 207(1), European Union, Consolidated Version of the Treaty on the Functioning of the European Union (2012) C326/01.

178 See, for instance, the BITs ratified by France, Germany, The Netherlands, Spain, the United Kingdom, $a t<$ italaw.com/resources/investment-treaties> (accessed 20 May 2015). 